\title{
Pengobatan Alternatif Tradisional Untuk Mencegah Penularan Covid-19 Menurut Perspektif Hukum Kekayaan Intelektual Di Kota Ambon
}

\author{
Ronald Saija $^{1 *}$, Teng Berlianty ${ }^{2}$, Pieter Radjawane ${ }^{3}$ \\ 1, 2, 3 Fakultas Hukum Universitas Pattimura, Ambon, Indonesia \\ *E-mail: ronaldreagensaija@gmail.com
}

Dikirim: 08/12/2021

Info Artikel
Keywords:
Alternative Medicine;
Covid-19 Prevention;
Intellectual Property
Rights.

Kata Kunci:

Pengobatan

Alternatif,

Pencegahan Covid19; Hak Kekayaan Intelektual.

\section{Direvisi: 08/05/2021}

Dipublikasi: 04/06/2021

\section{Abstract}

The success of vaccine development, one of the experiments to cure this virus, namely Traditional knowledge for most people has an important role for food security and the health of millions of people in developing countries. The purpose of this study was to determine and analyze the important role of the creator of traditional alternative medicine concoctions to prevent the transmission of Covid 19 in Ambon City, and the form of legal institutions by the Maluku Provincial Government to grant patents to the creators of traditional alternative medicine concoctions as local wisdom in handling treatment to prevent transmission. covid 19 in Ambon city. This research was conducted using an empirical juridical approach which is a descriptive study of qualitative analysis. The results showed that people in developing countries depend a lot on traditional medicine for up to $80 \%$ of their health needs. In addition, knowledge about health plants has become a source of modern medicine. The importance of the Government and society's attention to traditional knowledge and technology systems in Indonesia, especially in the field of herbal medicine. The occurrence of various polemics that often occur in the lives of indigenous peoples related to traditional healing for patients to prevent Covid-19 transmission in Ambon City.

\footnotetext{
Abstrak

Keberhasilan pegembangan vaksin, Salah satu eksperimental untuk menyembuhkan virus ini yakni Traditional knowledge bagi sebagian besar orang memiliki peranan penting untuk ketahanan pangan dan kesehatan jutaan orang di negara berkembang. Tujuan penelitian ini untuk mengetahui dan menganalisis pentingkah peran pencipta racikan obat alternatif tradisional untuk mencegah penularan Covid 19 di kota Ambon, dan bentuk pranata hukum oleh Pemerintah Provinsi Maluku untuk memberikan hak paten bagi pencipta racikan obat alternatif tradisional sebagai kearifan lokal dalam menangani pengobatan guna mencegah penularan covid 19 di kota Ambon. Penelitian ini dilakukan menggunakan pendekatan yuridis empiris yang bersifat kajian deskriptif analisis kualitatif. Hasil penelitian menunjukan bahwa Masyarakat pada negara berkembang banyak bergantung pada obat tradisional hingga $80 \%$ dari kebutuhan akan kesehatan mereka. Selain itu, pengetahuan tentang tanaman kesehatan telah menjadi sumber obat-obatan modern. Pentingnya
} 
DOI:

10.47268/sasi.v27i2.438 perhatian Pemerintah dan masyarakat terhadap sistem pengetahuan dan teknologi tradisional di Indonesia, khususnya dalam bidang obat herbal. Terjadinya berbagai polemik yang banyak terjadi pada kehidupan masyarakat negeri adat berhubungan dengan penyembuhan tradisional bagi pasien untuk mencegah penularan covid-19 di Kota Ambon.

\section{A. PENDAHULUAN}

Berawal dari kasus lokal, corona virus deasese (selanjutnya disebut covid-19) menyebar ke seluruh dunia silih berganti dengan cara penularan yang disebut sebagai kasus impor dari luar wilayah asal atau transmisi lokal antar penduduk. Sejauh ini, para ahli menduga bahwa covid 19 lebih kuat bertahan kuat di daerah bersuhu rendah dan kering, walaupun virus ini mewabah di negara-negara dengan kondisi suhu dan kelembaban udara yang sebaliknya.

Perkembangan virus ini lebih rentan menyebabkan kematian pada penduduk usia lanjut. Untuk pertama kalinya, China melaporkan adanya penyakit baru ini pada 31 Desember 2019. Pada penghujung tahun 2019, kantor World Health Organization (selanjutnya disebut WHO) di China mendapatkan pemberitahuan tentang adanya sejenis pneumonia yang penyebabnya tidak diketahui. Infeksi pernafasan akut yang menyerang paru-paru terdektesi di kota Wuhan, Provinsi Hubei, China. Menurut pihak berwenang menyebutkan ada beberapa pasien adalah pedagang yang beroperasi di pasar ikan Huanan. ${ }^{1}$

Penyebaran kasus Covid-19 pertama diluar Negara Tirai Bambu (China) ditemukan di Thailand pada 13 Januari 2020. Masih di benua Asia, pada 29 Januari 2020 Covid-19 mencapai Timur Tengah untuk pertama kalinya saat jumlah kasus Covid-19 bertambah dan menyebar ke lebih banyak negara. Saat itu Uni Emirat Arab melaporan kasus impor dalam keluarga empat orang. Empat hari sebelum Covid-19 mencapai kawasan Timur Tengah, dimana 2 Benua sekaligus juga melaporkan masuknya virus yang sama. Perancis menjadi negara pertama di benua Eropa yang menginformasikan tiga kasus Covid-19 yakni tanggal 25 Januari 2020.

Perkembangan Covid-19 masuk ke Indonesia yang dibawa oleh 2 WNI asal Jepang pada tanggal 2 Maret 2020, serta untuk pertama kalinya Presiden Joko Widodo mengumumkan secara resmi di Istana Negara. Pada tanggal 11 Maret 2020, untuk pertama kalinya warga negara Indonesia meninggal akibat Covid-19. Korban meninggal di Solo adalah seorang laki-laki berusia 59 tahun, yang sebelumnya diketahui pernah menghadiri seminar di kota Bogor, Jawa Barat tanggal 25-28 Pebruari 2020.

Pemerintah Republik Indonesia melalui Peraturan Pemerintah Pengganti Undang-undang (Perpu) nomor : 1 Tahun 2020 tentang Kebijakan Keuangan dan Stabilitas Sistem Keuangan untuk Penanganan Pandemi Corona virus Disease 2019 (Covid-19), lalu dengan Undangundang nomor : 6 tahun 2018 tentang Karantina Wilayah, serta Peraturan Pemerintah Nomor : 21 tahun 2020 tentang Pembatasan Sosial Berskala Besar (PSBB) dalam rangka Percepatan Penanganan Covid-19. Serta dengan dikeluarkannya Keputusan Presiden (Kepres) nomor 12 Tahun 2020 tentang Penetapan Bencana Non-Alam Penyebaran Covid-19 sebagai Bencana Nasional.

Penanggulangan bencana nasional yang diakibatkan oleh penyebaran Covid-19 dilaksanakan oleh Gugus Tugas Percepatan Penanganan Covid-19 sesuai dengan Keputusan Presiden Nomor 7 Tahun 2020 tentang Gugus Tugas Percepatan Penanganan Corona Virus Disease 2019 (COVID-19) sebagaimana telah diubah dengan Keputusan Presiden Nomor 9 Tahun 2020 tentang Perubahan atas Keputusan Presiden Nomor 7 Tahun 2020 melalui sinergi antar kementerian/lembaga dan Pemerintah Daerah.

\footnotetext{
Baskara, B. (2020). Rangkaian Peristiwa Pertama Covid-19. Kompas.id. https://www.kompas.id/baca/riset/2020/04/18/rangkaian-peristiwa-pertama-covid-19.
} 
Selanjutnya, reaksi dan ketetapan dimana para Gubernur, para Bupati, dan para Walikota sebagai Ketua Gugus Tugas Percepatan Penanganan Covid-19 di daerah, dalam menetapkan kebijakan di daerahnya harus memperhatikan kebijakan pemerintah pusat. Keputusan presiden ini mulai berlaku pada tanggal ditetapkan, yakni 13 April 2020. Pandemi virus corona (Covid19) membuat orang takut berobat ke rumah sakit, karena takut tertular virus mematikan itu. Namun, berobat ke rumah sakit seringkali tak bisa ditunda. Masa pandemi ini menuntut rumah sakit berbenah menghadapi new normal. Rumah sakit bakal menerapkan protokol kesehatan yang ketat untuk seluruh pengunjung, mulai dari pasien, keluarga atau pendamping pasien, hingga orang-orang yang bekerja di rumah sakit.

Indonesia bahkan dunia memberikan kesempatan bagi para ilmuwan untuk mengembangkan lebih dari 100 vaksin covid 19. Sebagian besar vaksin ini akan digunakan untuk membantu sistem kekebalan tubuh sebagai antibodi yang menempel pada protein, agar dapat menghambat serta menghentikan virus tersebut. Peneliti memperkirakan akan keberhasilan pegembangan vaksin tersebut, sebagai salah satu eksperimental untuk menyembuhkan virus ini.

Traditional knowledge atau pengetahuan tradisional merupakan salah satu isu menarik dan saat ini tengah berkembang dalam lingkup kajian HKI. Kekayaan intelektual yang dihasilkan oleh masyarakat adat/ asli/ tradisional ini mencakup banyak hal mulai dari sistem pengetahuan tradisional, karya-karya seni, karya sastra, filsafat, catatan perkembangan seni, sejarah, bahasa, ilmu hukum, wayang, batik, naskah klasik, naskah primbon, obat-obatan, hingga apa yang dikenal sebagai indigenous science and technology. Pengetahuan tradisional menjadi milik bersama dan belum secara tepat dilindungi dalam hukum kekayaan intelektual karena banyaknya pengetahuan tradisional Indonesia yang telah di daftarkan hak paten oleh orang asing, oleh karena itu bangsa Indonesia menyadari untuk berupaya melindunginya. ${ }^{2}$

Perlindungan kekayaan intelektual modern dilandasi oleh Perjanjian TRIPs (Trade Related Aspects of Intellectual Property Rights) sebagai salah satu agreement dalam Organisasi Perdagangan Dunia/ World Trade Organization (WTO). Keikutsertaan Indonesia di dalam TRIPs sesungguhnya merupakan pilihan yang dilematis. ${ }^{3}$ Hal ini diperkuat dengan rumusan The World Intellectual Property Organization (selanjutnya disebut WIPO) yang menyatakan bahwa "traditional knowledge systems in the field of medicine and healing, biodiversity conversation, the environtment and foods agriculture are well known". Pernyataan di atas menunjukkan bahwa pengetahuan obat tradisional merupakan bagian penting dari pengetahuan tradisional di samping ekspresi budaya tradisional seperti lagu-lagu dan karya seni. Bahkan diantara sekian banyak bentuk pengetahuan tradisional pengetahuan obat-obatan tradisional adalah yang perlu paling serius mendapat perhatian mengingat besarnya nilai ekonomi yang terkandung di dalamnya sehingga rentan terhadap tindakan didaftarkan menjadi hak bukan pemiliknya (misappropriation). Perlindungan harus diberikan untuk mencegah penyalahgunaan pengobatan, langkah perlindungan dilakukan untuk tujuan penghargaan pada nilai, sikap menghormati, dan memenuhi kebutuhan aktual masyarakat khususnya dalam hal ini adalah masyarakat pemilik produk herbal berbasis pengetahuan tradisional (selanjutnya disebut traditional knowledge). Perlindungan lebih jauh dilakukan untuk mencapai tujuan dan aspirasi masyarakat yang relevan, termasuk penghormatan terhadap hak budaya dan perlindungan tradisi berbasis kreativitas.

Traditional knowledge bagi sebagian besar orang memiliki peranan penting untuk ketahanan pangan dan kesehatan jutaan orang di negara berkembang. Masyarakat pada negara

2 Endang, P. (2005). Perkembangan Hukum Intellectual Property Right Kajian Hukum Terhadap Hak atas Kekayaan Intelektual dan Kajian Komparatif Hukum Paten. Bogor: Ghalia Indonesia, h. 245

3 Aryanto, H. (2014). Pemanfaatan Pengetahuan Tradisional Indonesia Berdasarkan Potensi Daerah sebagai Modal Pembangunan. Jurnal Hukum \& Pembangunan, 44(2), 292-313, DOI: http://dx.doi.org/10.21143/jhp.vol44.no2.24, h. 294.

$$
\text { 174|SASI Vo1. } 27 \text { No.2, April - Juni } 2021
$$


berkembang banyak bergantung pada obat tradisional hingga $80 \%$ dari kebutuhan akan kesehatan mereka. Selain itu, pengetahuan tentang tanaman kesehatan telah menjadi sumber obat-obatan modern. Kondisi ini sangat bertolak belakang dengan kebijakan pemerintah di bidang kesehatan, di mana otoritas kesehatan di Indonesia masih memandang khasiat obatobatan tradisional dengan sebelah mata dan masih menganak-emaskan obat farmasi modern. Kondisi ini dapat kita lihat dari rendahnya dukungan pemerintah untuk mengembangkan industri pengobatan tradisional herbal. ${ }^{4}$

Hasil dari kegiatan riset dan pengembangan tersebut yaitu produk pengembangan dengan kemasan baru, yang mereka sebut sebagai produk baru, seperti dalam bentuk obatobatan modern. Obat-obatan modern tersebut dimohonkan untuk didaftarkan hak paten dan diklaim sebagai miliknya sehingga menghilangkan asal usul dari produk tersebut, padahal hak paten tidak dapat diberikan kepada perusahaan multinasional tersebut jika dapat dibuktikan telah pernah ada sebelumnya (prior art). Tindakan mengklaim tersebut dikenal sebagai biopiracy. Pentingnya perhatian Pemerintah dan masyarakat terhadap sistem pengetahuan dan teknologi tradisional di Indonesia, khususnya dalam bidang obat herbal. Kasus jamu yang didaftarkan sebagai paten di luar negeri dapat menutup kemungkinan masyarakat adat untuk mengkomersilkan pengetahuannya karena pihak asing sudah mengklaim kepemilikan pengetahuan tersebut menurut skema Hak Kekayaan Intelektual. ${ }^{5}$

Keberadaan HKI memang tidak terlepas dari kegiatan ekonomi, industri dan perdagangan. Era globalisasi yang ditandai dengan perkembangan teknologi informasi dan telekomunikasi telah mendorong efesiensi dan efektivitas bagi para produsen untuk memasarkan produk-produknya ke luar negeri melalui pasar bebas. Sebagian besar barang dan jasa hasil karya intelektual yang diperdagangkan merupakan produk-produk teknologi mutakhir. Oleh karena itu, salah satu kunci kemajuannya adalah kemampuan melakukan inovasi di bidang teknologi. Dalam tatanan ekonomi global HKI dipandang sebagai masalah perdagangan yang mencakup interaksi dari tiga macam aspek utama, yaitu kekayaan intelektual, komersialisasi dan perlindungan hukum. Artinya, HKI menjadi penting ketika ada karya intelektual yang akan dikomersialkan sehingga pemilik karya intelektual tersebut membutuhkan perlindungan hukum formal untuk melindungi kepentingan mereka dalam memperoleh manfaat dari komersialisasi karya intelektualnya. Berdasarkan uraian singkat tersebut, jelas bahwa saat ini setiap proses komersialisasi dari setiap komiditi perdagangan, baik yang bernuansa ekspor maupun untuk pasar dalam negeri tidak dapat terlepas dari aspek perlindungan kekayaan intelektual.

Pembahasan tentang perlindungan traditional knowledge menjadi penting dilakukan dikarenakan: ${ }^{6}$ (1) nilai ekonomi, (2) pengembangan karakter bangsa yang terdapat pada traditional knowledge (identitas diri) dan (3) pemberlakuan rezim hak kekayaan intelektual yang tidak dapat dihindari lagi saat ini. Sedangkan menurut M. Hawin ${ }^{7}$ bahwa perlindungannya dirasakan penting mengingat: pertama, traditional knowledge merupakan sumber pengetahuan penting yang berhubungan dengan kehidupan manusia seperti pengobatan, makanan, minuman, pertanian, kesenian, dan lain sebagainya yang dapat dikomersilkan; kedua, sampai saat ini banyak traditional knowledge telah "dicuri" oleh banyak peneliti untuk dipakai sebagai a starting point dari penelitian mereka untuk mendapatkan paten.

\footnotetext{
4 Rasy, V. (2013). 30 Tanaman Herbal Untuk Pengobatan Tradisional. Yogyakarta: Penerbit Sakti.

5 Hilman, H., \& Romadoni, A. (2001). Pengelolaan \& Perlindungan Aset Kekayaan Intelektual: Panduan Bagi Peneliti Bioteknologi. Jakarta: British Council, h. 21.

6 Aulia, M. Z. (2006). Perlindungan Hak Kekayaan Intelektual atas Pengetahuan Tradisional, Karya Tulis. Lomba Karya Tulis Mahasiswa Bidang Hukum Se-Jawa 2006 tanggal 24 November 2006 di UNS, Surakarta, h.1.

7 Hawin, M. (2005), Perlindungan Pengetahuan Tradisional, Perlindungan dan Pemanfaatan Tradisional Knowledge Dalam Kerangka Otonomi Daerah, Makalah. Seminar setengah hari tanggal 20 Agustus 2005 , Yogyakarta, h. 1.

$$
\text { 175|SASI Vol. } 27 \text { No.2, April - Juni } 2021
$$
}


Upaya untuk melindungi pengetahuan tradisional dalam realitanya tidaklah semudah membalikan telapak tangan. Salah satunya disebabkan perspektif perlindungan dari negaranegara maju cenderung berbeda dengan perspektif negara-negara berkembang, dalam perspektif negara maju, mereka lebih berfikir bagaimana caranya untuk memperoleh akses seluas-luasnya kepada pengetahuan tradisional guna menciptakan produk-produk baru, dan mendapatkan keuntungan yang besar dari komersialisasi produk-produk tersebut. Sementara perspektif negara-negara berkembang, khususnya yang memiki keanekaragaman hayati dan pengetahuan tradisional yang melimpah, mereka lebih berfikir tentang bagaimana menciptakan sebuah mekanisme pembagian keuntungan yang adil dan seimbang atas pemaanfaatan keduanya. ${ }^{8}$

Masyarakat yang masih belum dapat menikmati pembangunan ekonomi, terutama yang berada di pedesaan atau hidup di luar urban area, termasuk di dalamnya masyarakat adat/ asli/ tradisional, tentunya menghadapi konsekuensi-konsekuensi akibat penerapan sistem HKI tersebut. Obat-obatan tradisional, teknik-teknik tradisional yang telah lama "hidup" dalam masyarakat adat/ asli/ tradisional tersebut, dianggap sebagai suatu aset yang bernilai ekonomis. Terdapat beberapa kasus HKI terkenal yang obyek atau sumber perselisihan hukumnya traditional knowledge. Sebagai contoh masalah pembatalan paten Shisedo atas ramuan tradisional Indonesia, Kasus paten basmawati rice antara India dan perusahaan multinasional (MNC) Amerika Serikat. Dalam kasus paten Turmenic (1996), University of Mississippi Medical Centre di Amerika Serikat telah memperoleh paten dari USPTO (patent number 5401504) atas curcuma longa yang oleh masyarakat tradisional India digunakan dalam berbagai keperluan seperti untuk kosmetik, obat-obatan, penyedap rasa makanan, dan lainnya. ${ }^{9}$

Dari kasus tersebut dapat diambil pelajaran bahwa perlindungan terhadap traditional knowledge bisa mendapat perlindungan namun belum efektif dan solutif. Selain itu sejauh mana traditional knowledge mendapat perlindungan sebagai HKI sampai sekarang pun belum ada kesepakatan secara Internasional. Apabila keunikan, ciri khas dan kualitas dari traditional knowledge tersebut dapat dipertahankan serta dijaga konsistensi mutu tingginya, maka produk kekayaan tradisional tersebut akan tetap mendapatkan pasaran yang baik, tidak hanya dipasaran dalam negeri saja, bahkan dapat diekspor dan bersaing di tingkat internasional. Salah satu alternatif yang digunakan masyarakat untuk mencegah penularan covid 19 yaitu menggunakan pengobatan alternatif tradisional meliputi obat herbal di berbagai daerah. Obat tradisional adalah obat yang diolah secara tradisional, turun temurun, berdasarkan resep nenek moyang, adat istiadat, kepercayaan atau kebiasaan setempat baik bersifat magic maupun pengetahuan tradisional. $^{10}$

Dari pengertian di atas nampak bahwa lahirnya pengetahuan obat-obatan tradisional (selanjutnya disebut POT) melibatkan proses "mencipta" atau mengkreasikan bahan-bahan yang disediakan oleh alam menjadi media penyembuhan. Sehingga, jika dikaitkan dengan pengertian Hukum Kekayaan Intelektual (selanjutnya disebut HKI) yang menyatakan bahwa setiap bentuk Hak Kekayaan Intelektual merupakan hasil kreativitas manusia dalam berbagai wujud dan berguna dalam kehidupannya maka sudah jelas bahwa pengetahuan obat-obatan tradisional merupakan bagian dari Hak Kekayaan Intelektual.

Dimana para penyembuh tradisional ini dipandang sebagai orang-orang "istimewa" yang mendapat kemampuan "lebih" dari yang Maha Kuasa. Pengetahuan obat-obatan tradisional menjadi bagian dari budaya karena sifat pengetahuan tersebut yang lebih banyak dalam bentuk

${ }^{8}$ Labetubun, M. A. H., Akyuwen, R. J., \& Pariela, M. V. G. (2018). Perlindungan Pengetahuan Tradisional Secara Sui Generis untuk Menyongsong Masyarakat Ekonomi Asean. Sasi, 24(1), 1-10, h. 8.

9 Sardjono, A. (2004). Pengetahuan Tradisional: Studi Mengenai Perlindungan Hak Kekayaan Intelektual Atas Obat-Obatan. Jakarta: Fakultas Hukum Universitas Indonesia, h. 26.

10 i.d.wikipedia.org/wiki/obat_tradisional

$$
\text { 176|SASI Vol. } 27 \text { No.2, April - Juni } 2021
$$


lisan, diturunkan secara turun temurun dari satu generasi ke generasi berikutnya dan menjadi pengetahuan milik bersama semua anggota komunitas.

Minimnya pemahaman masyarakat lokal mengenai pentingnya Hak Kekayaan Intelektual (selanjutnya disebut HKI), membuat mereka tidak tertarik untuk mengambil manfaat ekonomi dari Pengetahuan Tradisional Tersebut. ${ }^{11}$ Peluang mana yang justru terbaca dengan jelas oleh industri-industri farmasi dari negara maju yang kemudian memanfaatkan pengetahuan obatobatan tradisional tersebut tanpa ijin dan kompensasi yang wajar bagi masyarakat pemilik pengetahuan tradisional. Sehingga jika dikaji setidaknya ada 3 (tiga) alasan yang melandasi perlunya perlindungan hukum bagi pengetahuan obat-obatan tradisional tersebut sebagaimana dipaparkan oleh Agus Sardjono berikut ini: a. Pengetahuan obat-obatan tradisional Indonesia sejak lama telah dikomersialisasikan oleh negara-negara lain; b. Untuk memperkuat posisi dalam sistem perdagangan dunia; c. Untuk melindungi kepentingan masyarakat lokal. ${ }^{12}$ Berdasarkan hal diatas, terjadinya berbagai polemik yang banyak terjadi pada kehidupan masyarakat negeri adat pada empat kecamatan berhubungan dengan penyembuhan tradisional bagi pasien untuk mencegah penularan covid 19 di Kota Ambon.

\section{B. METODE PENELITIAN}

Metode pendekatan yang digunakan dalam penelitian ini adalah yuridis empiris yang bersifat kajian deskriptif analisis kualitatif. Penelitian ini berusaha untuk menggambarkan akibat hukum terhadap Pengobatan Alternatif Tradisional Untuk Mencegah Penularan Covid 19 Menurut Perspektif Hukum Kekayaan Intelektual di Kota Ambon, di Negeri Hative Besar (Saharoe Besar) di Kecamatan Teluk Ambon, Negeri Soya di Kecamatan Sirimau, Negeri Latuhalat di Kecamatan Nusaniwe, Negeri Hatalai, Negeri Naku, Negeri Kilang, Negeri Ema, Negeri Hukurila, Negeri Hutumuri, Negeri Rutong, Negeri Leahari di Kecamatan Leitimur Selatan. Teknik pengumpulan data yang digunakan dalam penelitian ini yaitu: Wawancara, kuesioner dan studi kepustakaan

\section{PEMBAHASAN}

\section{Peran Penting Tabib Adat Sahoeroe dalam Pengobatan Tradisional untuk Mencegah Penularan Covid 19 di Kota Ambon}

Meluasnya sebaran Covid 19 tersebut telah berimplikasi terhadap berbagai aspek kehidupan masyarakat di bidang ekonomi, termasuk pangan, sosial, budaya, dan hukum. Ini berarti dalam menghadapai pandemi Covid 19, salah satu hal pokok yang perlu menjadi perhatian pemerintah adalah penggunaan obat tradisional sebagai penangkal penularan covid$19^{13}$. Undang-Undang Nomor 23 tahun 1992 tentang Kesehatan disebutkan bahwa obat tradisional adalah bahan atau ramuan bahan yangberupa bahan tumbuhan, bahan hewan dan bahan mineral, serdiaan sarian (galenie) atau campuran bahan tersebut yang secara turun temurun telah berkembang, obat tardsional te;ah dimanfaatkan dalam pelayanan kesehatan terutama dalam pelayanan kesehatan strata pertama. Sementara itu di banyak negara maju penggunaan obat tradsional makin populer.

Penggunaan obat tradisional di Indonesia merupakan bagian dari budaya bangsa dan telah dimanfaatkan oleh masyarakat sejak berabad-abad. Namun demikian secara umum efektivitas dan keamananya belum sepenuhnya didukung hasil penelitian yang memadai. Mengingat hal tersebut dan menyadari bahwa Indonesia sebagai mega-center tanaman obat di dunia, maka

\footnotetext{
${ }^{11}$ Yessiningrum, W. R. (2015). Perlindungan Hukum Indikasi Geografis Sebagai Bagian Dari Hak Kekayaan Intelektual. Jurnal IUS Kajian Hukum dan Keadilan, 3(1), 42-53, h. 43.

12 Agus, S. (2010). Hak Kekayaan Intelektual Dan Pengetahuan Tradisional. Bandung: Alumni. h. 2-3

13 Rato, D., Utomo, L., Jayantiari, I. G. A. M. R., Bustami, S., Tehupeiory, A., Trisia, M. A.,...\& Geme, M. T. (2020). Kearifan Lokal Masyarakat Hukum Adat dalam Mewujudkan Kedaulatan Pangan Ditengah Pandemi Covid 19. Journal of Indonesian Adat Law (JIAL), 455-455.
}

$$
\text { 177|SASI Vo1. } 27 \text { No.2, April - Juni } 2021
$$


perlu adanya suatu kebijakan nasional yang dapat menjadi acuan semua pihak yang terkait didalamnya.

Indonesia disebut memiliki potensi bahan baku obat herbal yang tinggi, sehingga sangat disayangkan jika tidak dimanfaatkan secara maksimal dalam merespon kebutuhan obat untuk menangkal penyakit ini. Apalagi di era new normal (normal baru), masyarakat diminta tetap menjalankan aktivitas normal, sehingga imunitas yang sehat merupakan syarat utama untuk menangkal penularan Covid-19 agar tetap produktif baik di dalam ataupun di luar rumah.

Penggunaan herbal dapat meningkatkan fungsi kekebalan tubuh. Kekebalan tubuh yang optimal dapat mencegah tubuh dari infeksi COVID-19 (penyakit Coronavirus-19). Keterbatasan penelitian ini adalah validitas data yang perlu dilakukan melalui triangulasi konten media online dan laporan ilmiah yang dibuat oleh para ahli dari berbagai laboratorium terkemuka. Oleh karena itu, penelitian selanjutnya perlu meninjau topik penelitian ini menggunakan teknik analisis triangulasi media online dan laporan penelitian yang dikeluarkan oleh laboratorium terkemuka di Indonesia. ${ }^{14}$

Tanaman yang memiliki potensi sebagai antiviral yang dapat menghambat COVID-19 antara lain: jahe merah (Zingiber officinale), kunyit (Curcuma longa L.), temulawak (Curcuma xanthorriza Roxb), teh hijau (Camelia sinensis), meniran (Phyllantus niruri L.), salam (Syzygium polyanthum), jambu biji (Psidium guajava), cengkeh (Sygizium aromaticum), dan bawang putih (Allium Sativum). ${ }^{15}$ Tanaman herbal sebagai bahan utama obat tradisional memiliki kandungan yang berfungsi sebagai imunomodulator, mengurangi gejala dan mengatasi komorbid Covid-19. Tanaman herbal sangat baik digunakan dalam kondisi pandemi saat ini. Meskipun memiliki banyak fungsi, penggunaan tanaman herbal perlu pengolahan yang benar, kadar yang sesuai kebutuhan tubuh serta perlu uji fitofarmaka. ${ }^{16}$

Pilihan pengobatan akan disesuaikan dengan kondisi pasien dan tingkat keparahannya. Beberapa pasien dengan gejala ringan atau tanpa gejala akan di sarankan untuk melakukan protokol isolasi mandiri di rumah sambil tetap melakukan langkah pencegahan penyebaran infeksi virus Corona. Di negeri Hative Besar, ada beberapa warga masyarakat setempat yang mengalami gejala corona virus ini. Gejala corona visrus yang lebih dikenal dengan nama covid 19, ternyata dapat disembuhkan menggunakan pengobatan tradisional. Dalam tindakan pencegahan pernularan covid 19 oleh seorang pencipta racikan obat alternatif tradisional yang berdomisili Sahoeroe di Negeri Hative Besar yang bernama Onifaris Tuhuleruw.

Onifaris Tuhuleruw lebih dikenal dengan sapaan keseharian "bapa Nyong" adalah seorang Tabib Adat (dikenal dengan sebutan tukang barobat kampung). Dari tindakannya untuk menolong setiap warga masyarakat yang mengalami berbagai penyakit termasuk gejala covid 19. Pengobatan alternatif adalah segala bentuk pengobatan menggunakan cara, alat dan bahan yang tidak termaksud di dalam standar pengobatan modern. Pengobatan alternatif dapat berupa pengobatan tradisional, pengobatan dengan kepercayaan, pengobatan herbal dna lain sebagainya.

Bapa Nyong yang akrab disapa oleh setiap pasiennya melakukan pengobatan bagi mereka yang menderita berbagai penyakit termasuk penyakit corona yang telah tepapar gejala-gejala

14 Anggraeni, A. D., Salahudin, S., Jamil, A. S., \& Rofida, S. (2021). Analisis Kualitatif Obat Tradisional Sebagai Agen Peningkatan Imunitas Tubuh dalam Melawan Covid-19 Di Surat Kabar Online Indonesia. JKM (Jurnal Kesehatan Masyarakat) Cendekia Utama, 8(2), 207-226. DOI: https://doi.org/10.31596/jkm.v8i2.684, h. 207.

15 Dewi, Y. K., \& Riyandari, B. A. (2020). Potensi Tanaman Lokal sebagai Tanaman Obat dalam $\begin{array}{llll}\text { Menghambat } \quad \text { Penyebaran } & \text { COVID-19. Jurnal } & \text { Pharmascience, 7(2), }\end{array}$ DOI: http://dx.doi.org/10.20527/jps.v7i2.8793, h. 112

16 Perdani, M. S., \& Hasibuan, A. K. (2021). Analisis Informasi Tanaman Herbal melalui Media Sosial ditengah Masyarakat pada Pandemi Covid-19: Sebuah Tinjauan Literatur. BENCOOLEN JOURNAL OF PHARMACY, 1(1), 11-25. DOI: https://doi.org/10.33369/bjp.v1i1.15589, h. 11.

$$
\text { 178|SASI Vol. } 27 \text { No.2, April - Juni } 2021
$$


umum meliputi demam, batuk kering dan letih, bahkan gejala tidak umum meliputi rasa tidak nyaman dan nyeri, nyeri tenggorokkan, diare, sakit kepala. Adapun komposisi yang dipergunakan dalam obat racikan tradisional (obat sahoeroe) meliputi daun sirih bulu yang agak menguning atau tua, kunyit raja atau kuning kepala, dan garam dapur sebanyak 3 butir. Ini gambarnya:
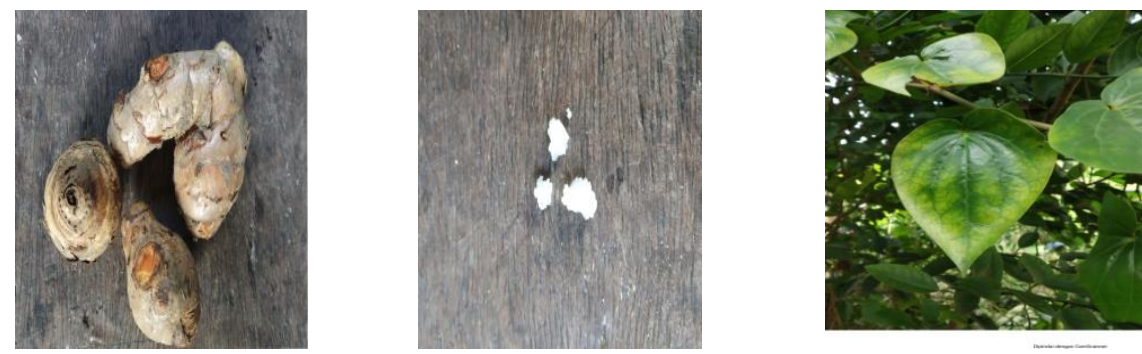

Gambar 1. Komposisi obat racikan tradisional.

Berdasarkan manfaat pada ketiga bahan diatas, yakni daun sirih bulu matang'menguning, kunyit raja dan 3 butir garam dapur. Apabila disatukan, maka terdapat terdapat khasiat dari masing-masing bahan tersebut dapat menyembuhkan covid 19. Obat racikan bapa Nyong dapat menyembuhkan penderita yang mengalami gejala covid 19 yakni gabungan racikan daun sirih bulu yang telah tua atau menguning, kunyit raja atau kuning mai, dan 3 butir garam dapur. Caranya: siapkan selembar daun sirih bulu yang bersih, kemudian tumbuk kunyit raja secukup serta memasukan 3 butir garam dapur mejadi satu. Setelah itu, obat racikan dikunyah hingga mengeluarkan kuah atau sari. Sari atau kuah obat tersebut ditelan, setelah itu khasiatnya dapat menyembuhkan penyakit covid dalam waktu 30 menit sampai dengan 2 jam. Obat ini pada mulanya merupakan obat mimpi yang didapatkan melalui mimpi. Percaya atau tidak percaya, obat sahoeroe ini dapat menyembukan penyakit covid 19 secara ajaib. Memang belum ada uji laboratorium sebelumnya mengenai khasiat dari racikan obat sahoeroe tersebut. Dengan rasa percaya diri, pencipta racikan ini menyatakan bahwa khasiat dari obat racikan "Sahoeroe" ini membawa manfaat kesembuhan bagi para pasiennya (warga masyarakat desa) yang mengalami gejala-gejala covid 19 .

Sumber daya alam bahan obat dan obat tradisional merupakan aset nasional yang perlu terus digali, diteiti, dikembangkan dan dioptimalkan pemanfaatannya. Sebagai suatu negara dengan wilayah yang mempunyai tingkat keanekaragaman hayati yang tinggi, potensi sumber daya tumbuhan yang ada merupakan suatu aset dengan nilai keunggulan komparatif dan sebagai modal dasar utama dalam upaya pemanfaatan dan pengembangannya untuk menjadi komoditi yang kompetitif.

Bapa Nyong melakukan pengobatan alternatif tradisional kepada siapa saja yang meminta bantuannya untuk diobati, termasuk penyakit corona virus. Ada pengakuan dari beberapa orang penderita yang mengalami gejala penyakit corona virus yang telah sembuh dengan menggunakan pengobatan alternatif tradisional, antara lain: 1. Ronald Tuhuleruw (50 Tahun); 2. Frijon Tuhuleruw (36 Tahun); 3. Nova Sahupala/Warkor (45 Tahun) dan beberapa warga Negeri Hukurila yang tidak mau menyebutkan nama mereka. Adapun pengakuan dari warga masyarakat yang mengalami proses kesembuhan dengan menggunakan racikan "obat sahoeroe", antara lain:

1) Ronald Tuhuleruw, 59 Tahun

Dia (Ronald Tuhuleruw) pernah mengalami gejala covid 19 saat sedang beraktivitas di laut. Setelah pulang dia merasakan tubuhnya sangat letih dan lelah, serta demam tinggi. Kemudian dia memanggil bapa Nyong (saudara Kandungnya) untuk memberikan obat sahoeroe untuk dikunyah serta menelan air dari racikan obat herbal 
tersebut. Dia merasakan khasiat obat sahoeroe pada saat menelan airnya. Tubuhnya merasakan kuat dan sehat, setelah adanya reaksi dari obat yang dikunyah tadi. Menurutnya, gejala-gejala penyakit corona virus ini sangat ganas menyerang sistem kekebalan pada tubuh seseorang. Apabila tidak ada pertolongan dari bapa Nyong dengan racikan obat sahoeroe, maka dia tidak dapat bergerak. ${ }^{17}$

2) Frijohn Tuhuleruw, 36 Tahun

Dia (Frijohn Tuhuleruw) menjelaskan bahwa dia mengalami sesak nafas sejak bekerja sebagai Polisi Bandara Pattimura Ambon. Dia merasakan sesak nafas dan sulit menelan makanan, serta merasakan tubuhnya demam tinggi. Dia merasakan hanya sakit demam biasa, dan sering menggunakan obat dari apotik untuk menurunkan demamnya. Setelah 4 hari berlalu, dia merasakan badannya lemas dan sulit untuk bernafas. Dia menyuruh isterinya untuk memanggil bapa Nyong untuk memberikan pertolongan. Saat itu, bapa Nyong menggunakan racikan obat sahoeroe (daun sirih yang menguning, 3 butir garam dapur dan kunyit mai (kunyit raja), kemudian dia mengunyah dan menelan airnya (kuah). Setelah beberapa saat kemudian, dia merasakan perlahan-lahan tenggorokan dan dadanya tidak sesak lagi, kemudian dia makan dengan cara mengunyah obat sahoeroe tersebut beberapa kali. Setelah itu, dia mengatakan bahwa dia sehat dan bisa melakukan aktifitasnya sebagai aparat penegak hukum di Bandara Pattimura Ambon. ${ }^{18}$

3) Nova Sahupala/Warkor, 45 Tahun

Dia (Nova Sahupala/Warkor) sebenarnya tidak merasakan gejala apa-apa, pada saat melakukan tes Sweb dan melihat hasilnya positif covid 19. Kakaknya (Cores Sahupala) langsung menghubungi bapa Nyong untuk minta obat sahoeroe tersebut. Setelah obat tersebut didapatkan, kemudian dia (Nova) langsung mengunyah serta langsung menelan airnya (kuah) beberapa kali. Kemudian dia coba tes sweb ulang, ternyata langsung dikatakan negatif artinya bebas covid $19 .{ }^{19}$

Berdasarkan hasil wawancara penulis dengan para penderita gejala Covid 19 diatas, maka dalam proses penyembuhan tersebut masih bersifat tradisional belum adanya sentuhan penelitian vaksinasi lebih lanjut dari Pemerintahan Kota Ambon dan Dinas Kesehatan Kota Ambon. Perlindungan harus diberikan untuk mencegah penyalahgunaan pengobatan, langkah perlindungan dilakukan untuk tujuan penghargaan pada nilai, sikap menghormati, dan memenuhi kebutuhan aktual masyarakat khususnya dalam hal ini adalah masyarakat pemilik produk herbal berbasis pengetahuan tradisional (selanjutnya disebut traditional knowledge). Perlindungan lebih jauh dilakukan untuk mencapai tujuan dan aspirasi masyarakat yang relevan, termasuk penghormatan terhadap hak budaya dan perlindungan tradisi berbasis kreativitas. Traditional knowledge bagi sebagian besar orang memiliki peranan penting untuk ketahanan pangan dan kesehatan jutaan orang di negara berkembang. Masyarakat pada negara berkembang banyak bergantung pada obat tradisional hingga $80 \%$ dari kebutuhan akan kesehatan mereka. Selain itu, pengetahuan tentang tanaman kesehatan telah menjadi sumber obat-obatan modern. Kondisi ini sangat bertolak belakang dengan kebijakan pemerintah di bidang kesehatan, di mana otoritas kesehatan di Indonesia masih memandang khasiat obatobatan tradisional dengan sebelah mata dan masih menganak-emaskan obat farmasi modern. Kondisi ini dapat kita lihat dari rendahnya dukungan pemerintah untuk mengembangkan industri pengobatan tradisional herbal.

Hak Kekayaan Intelektual (HKI) menjadi salah satu altematif dalam pembangunan ekonomi bangsa karena memiliki kontribusi ekonomi yang signifikan bagi perekonomian Indonesia, seperti menciptakan iklim bisnis yang positif, memperkuat citra dan identitas bangsa

17 Wawancara dengan Bapak Ronald Tuhuleruw, tanggal 3 Agustus 2020

18 Wawancara dengan Bapak Frijohn Tuhuleruw, tanggal 12 Agustus 2020

19 Wawancara dengan ibu Nova Sahupala/Warkor, tanggal 24 Agustus 2020.

180|S A S I Vol. 27 No.2, April - Juni 2021 
Indonesia, mendukung pemanfaatan sumber daya yang terbaru, menjadi pusat penciptaan inovasi dan pembentukan kreativitas serta dapat mencetak generasi-generasi muda yang potensial dan memiliki dampak sosial yang positif lainnya ${ }^{20}$.

Hak kekayaan intelektual (HKI) merupakan hak milik yang berasal dari kemampuan intelektual yang diekspresikan dalam bentuk ciptaan hasil kreativitas melalui berbagai bidang, seperti ilmu pengetahuan, teknologi, seni, sastra, desain, dan sebagainya. Menurut Peter Mahmud Marzuki, ${ }^{21}$ HKI adalah suatu hak yang timbul dari karya intelektual seseorang yang mendatangkan keuntungan materiil. Secara lebih jelas Muhamad Djumhana dan R. Djubaedillah $^{22}$ menyimpulkan bahwa HKI merupakan suatu hak yang berasal dari kegiatan kreatif suatu kemampuan berdaya pikir manusia yang diekspresikan kepada khalayak umum dalam berbagai bentuk, yang memiliki manfaat serta berguna dalam menunjang kehidupan manusia, juga mempunyai nilai ekonomi. Atas hasil kreasi tersebut, dalam masyarakat beradab diakui bahwa yang menciptakan boleh menguasai untuk tujuan yang menguntungkan. Kreasi sebagai milik berdasarkan postulat hak milik dalam arti seluas-luasnya yang juga meliputi milik yang tidak berwujud. Dalam rangka melindungi HKI, selain memperhatikan cakupan dari HKI itu sendiri, juga perlindungan tersebut dapat didasarkan pada hukum yang berada di luar HKI. Beberapa negara seperti Amerika Serikat telah memperkenalkan hukum Anti Monopoli yang mencoba mengisi beberapa jurang pemisah dalam kaitannya dengan perlindungan yang tidak tercakup dalam hukum HKI sehingga penghargaan dapat diberikan kepada orang-orang yang telah menanamkan modalnya untuk mendapatkan informasi atau mencipta sesuatu yang untuk alasan-alasan tertentu, tidak dilindungi berdasarkan prinsip-prinsip tradisional HKI. Indonesia memiliki sekitar 400 suku bangsa (etnis dan sub-etnis). Maing-masing etnis dan sub-etnis memiliki berbagai penegtahuan yang diwariskan dari generasi ke generasi, diantaranya adalah pengetahuan tradisional di bidang pengobatan dan obat-obatan.

Menurut penulis bahwa pentingnya penemuan obat racikan alternatif tradisional "Obat Sahoeroe" menjadi fenomena positif untuk menyembuhkan covid 19. Penulis mangharapkan adanya koordinasi yang dengan pihak terkait berkaitan dengan pemberian ijin praktek peracik obat tradisional/Tabib Adat dari Kementerian Hukum dan Hak Asasi Manusia Propinsi Maluku, Dinas Ksehatan Maluku, dan Pemerintahan Kota Ambon untuk memberikan hak paten bagi pencipta racikan tradisional sebagai salah satu kearifan lokal di Provinsi Maluku.

\section{Bentuk Pranata Hukum Paten oleh Pemerintah Provinsi Maluku bagi Pencipta Racikan Obat Alternatif Tradisional}

Tabib seringkali dimaknai dengan dukun atau dokter, yang dimaksud dengan tabib merupakan orang yang pekerjaannya mengobati orang sakit secara tradsional. Istilah Tabib dalam Kamus Besar Bahasa Indonesia menyatakan bahwa Tabib adalah orang yang pekerjaannya mengobato orang sakit secara tradisional, seperti dukun. Tabib bisa dijumpai dalam kehidupan masyarakat adat di Maluku pada umumnya, berbeda dengan dokter. Biasanya tabib ini mengobati orang sakit dengan menggunakan ramuan obat alternatif tradisional berupa bahan herbal. Segala perbuatan tabib untuk menolong mengobati orang sakit sangat dibutuhkan warga masyarakat yang kurang mampu di negeri-negeri adat serta tergolong murah.

Proses pengobatan tabib adat ini dilakukan secara turun-temurun dari generasi ke generasi selama berabad-abad, tanpa adanya keahlian khusus, seperti seseorang dokter. Tabib adat merupakan salah satu kegiatan seorang anak adat untuk mengobati orang sakit tanpa

20 Labetubun, M. A. H. (2019). Penyelesaian Sengketa Hak Atas Logo (Suatu Kajian Overlapping Hak

Cipta dan Merek). ADHAPER: Jurnal Hukum Acara Perdata,5(1), 151-166. DOI: https://doi.org/10.36913/jhaper.v5i1.93, h. 152.

21 Marzuki, P. M. (1996). Pemahaman Praktis Mengenai Hak Milik Intelektual. Jurnal Hukum Ekonomi, FH UNAIR Edisi III, h. 41.

22 Djumhana, M., \& Djubaedillah, R. (2014). Hak Milik Intelektual (Sejarah Teori dan Prakteknya di Indonesia), Bandung: Penerbit Citra Aditya Bakti, h. 23.

$$
\text { 181|SASI Vo1. } 27 \text { No.2, April - Juni } 2021
$$


membutuhkan bayaran yang mahal, kadangkala tidak dipungut biaya (sukarela). Warga masyarakat yang sakit sangat membutuhkan tabib sebagai pertolongan pertama dikala dokter tidak ada di negeri yang jauh dari kota. Untuk itu, menurut penulis bahwa Tabib adat ini dalam menjalankan aktivitas untuk mengobati orang sakit harus diberikan apresiasi dari pemerintah untuk memberikan penghargaan atas karya ramuan obat tradisional dalam pengobatannya disebut dengan pemberian hak paten. Obat tradisional telah diterima secara luas di negaranegara yang tergolong berpenghasilan rendah sampai sedang. Bahkan dibeberapa negara berkembang obat tradisional telah dimanfaatkan dalam pelayanan kesehatan, terutama dalam pelayanan kesehatan strata pertama. Sementara itu, di banyak negara maju penggunaan obat tradisional semakin populer.

Paten merupakan sebuah hak eksklusif untuk memanfaatkan (membuat, menggunakan, menjual) hasil invensi dalam jangka waktu tertentu dan pada lingkup di mana paten tersebut didaftarkan. Hak paten diberikan untuk sebuah penemuan yang memenuhi persyaratan asli (novelty), bersifat baru atau inventif (non-obviousness), dan berpotensi membangkitkan nilai ekonomi dan kemanfaatan bagi masyarakat (usefulness). Selain hak monopoli terbatas berupa paten, OECD (2004) menyebutkan beberapa jenis hak monopoli terbatas lain yang pada umumnya diperuntukkan bagi benda-benda tak berwujud (intangible asset), seperti halnya hak cipta (copyright), merek dagang (trademark), dan perlindungan desain produk (design protection).

Mekanisme perlindungan paten mengarahkan pengertian paten sebagai suatu invensi yang dibuka secara komprehensif dalam kerangka formal sehingga pihak lain mengetahui dan mengakui apa yang telah dihasilkan oleh inventor. Terkait dengan nilai ekonomi, paten terkait dengan hak monopoli terbatas bagi seorang inventor. Dasar bagi pentingnya paten adalah perlunya pengakuan dan perlindungan bagi inventor atas usaha dan biaya yang telah dikeluarkan dalam menghasilkan temuan-temuan baru yang bermanfaat.

Terkait dengan peran teknologi sebagai sumber pertumbuhan ekonomi dan aktivitas inovasi dalam mendorong perkembangan teknologi yang bermanfaat bagi kehidupan, appropriability atau kemampuan seorang inventor dalam menangkap nilai ekonomi dari pengetahuan dan kompetensi yang dimiliki menjadi isu yang penting. Menjawab pertanyaan "who profits from innovation", Teece (2000) menggambarkan dua mekanisme (formal methods dan informal methods) dalam mekanisme appropriability. Metode formal terdiri atas patents, trade marks, registration of design, dan copyrights. Adapun metode informal sering kali dilakukan dengan trade secrets, tead times, complexity of design, complementary sales and service, dan complementary manufacturing/ operations. Dua metode appropriability di atas umum digunakan oleh para pelaku bisnis dalam menjaga kelangsungan dan keberlanjutan dari aktivitas inovasi mereka.

Terkait dengan pentingnya pengakuan HKI dan kemampuan para pelaku inovasi dalam menangkap nilai ekonomi, studi ini berupaya untuk memahami para pelaku inovasi di perekonomian Indonesia dalam melindungi hasil temuan mereka dengan menggunakan metode formal appropriability terutama paten. Studi ini penting, baik dari sisi kebijakan publik maupun dari sisi akademis. Pengembangan perspektif kebijakan publik terkait kebijakan paten dalam mendorong aktivitas inovasi dan realisasi konsep good governance di area ini akan berkontribusi dan memperkaya pengetahuan, baik dari sisi kebijakan maupun sisi akademis.

Dewasa ini pengakuan HKI mendapat perhatian besar selaras dengan proses perdagangan bebas. Pentingnya pengakuan HKI ini terkait dengan perlindungan terhadap produk-produk perdagangan dari berbagai pola imitasi, pemalsuan produk, dan ssbagainya. Era perdagangan bebas tersebut melibatkan berbagai aspek hukum perdagangan nasional yang harus disepakati oleh semua negara yang terlibat di dalamnya.

Rendahnya jumlah paten di Indonesia harus dilihat dalam kerangka yang komprehensif, baik dari sudut pandang efektivitas kebijakan paten dalam mendorong inovasi maupun kinerja 
litbang dan inovasi di tingkat mikro. Membandingkan jumlah permohonan paten selama tiga periode undang-undang paten (UUP No. 6/1989, UUP No. 13/1997, dan UUP No. 14/2001) tampak jelas bahwa permohonan paten Indonesia masih sangat tertinggal dari permohonan paten oleh asing.

Pengelolaan HKI menjadi isu yang perlu diperhatikan. Selama ini pengelolaan HKI di Indonesia masih ditangani oleh Departemen Hukum dan HAM. Berbeda dengan yang terjadi di Indonesia, pengelolaan HKI di negara-negara maju seperti Amerika Serikat, Korea Selatan, dan Jepang sudah ditangani oleh badan-badan independen. Manfaat pengelolaan HKI oleh badanbadan independen di negara-negara tersebut adalah keluwesan dan efektifnya badan-badan independen tersebut menghubungkan sisi penawaran dan permintaan produk-produk invensi yang sudah dipatenkan. Kebijakan pengelolaan HKI pada dasarnya tidak hanya berupa aktivitas pendaftaran produk-produk invensi dan menciptakan skema keterbukaan informasi produk yang bersangkutan, namun juga bagaimana produkproduk invensi tersebut dapat memasuki tahap pemanfaatan yang memiliki nilai tambah ekonomi. Pemikiran ini mendasari pertanyaan sudah efektifkah sistem pengelolaan HKI di Indonesia dalam upaya mendorong aktivitas inovasi di tingkat makro.

Paten merupakan sebuah indikator dari bekerjanya Sistem Inovasi Nasional (SIN) di sebuah perekonomian. Semakin besar jumlah paten yang dihasilkan di sebuah negara mengindikasikan semakin tingginya kapabilitas inovasi di negara yang bersangkutan. Kapabilitas inovasi tersebut menandakan bekerjanya aktivitas penelitian dan pengembangan (litbang) yang melibatkan interaksi elemen sistem inovasi (perguruan tinggi, lembaga litbang, dan industri) di negara yang bersangkutan.

Belum optimalnya instrumen paten dalam mendukung daya saing produk-produk industri di Indonesia, masih rendahnya kesadaran akan pentingnya paten, dan berbagai permasalahan terkait pelanggaran pengakuan HKI menjadi dasar bagi studi ini untuk mengkaji kebijakan paten dalam kerangka mendorong bekerjanya SIN. Terlepas dari perdebatan terkait dengan dampak positif dan negatif paten terhadap kompetisi dan aktivitas teknologi, studi ini akan mengkaji dan menyintesiskan bagaimana kebijakan paten dalam mendorong bekerjanya SIN di Indonesia. Sudut pandang kebijakan inovasi dipandang lebih tepat dalam menempatkan paten sebagai sebuah instrumen untuk mendorong aktivitas inovasi dengan melibatkan berbagai penyesuaian dengan kebijakan inovasi pada skala yang lebih besar. Sebagaimana pemikiran dari ahli-ahli ekonomi dewasa ini bahwa paten dapat dimanfaatkan sebagai sebuah instrumen kebijakan untuk mendorong inovasi di level mikro. Hal ini mengimplikasikan bahwa kebijakan paten ini akan bersifat komplementer dengan instrumen-instrumen kebijakan yang lain seperti hibah, berbagai bentuk mekanisme subsidi dan berbagai aktivitas kebijakan publik untuk mendorong aktivitas litbang. Menempatkan kebijakan paten untuk mendorong aktivitas inovasi dengan kerangka SIN diharapkan mampu memberikan hasil kajian pemanfaatan kebijakan paten yang efektif dalam mendorong aktivitas inovasi di Indonesia.

Mengkaji hubungan kebijakan paten dan dampaknya bagi aktivitas litbang dan inovasi pada elemen SIN, studi ini memandang perlu untuk melakukan kajian terkait dengan faktorfaktor yang berhubungan dengan lemahnya produktivitas paten di Indonesia. Studi ini menetapkan dua hal, yaitu 1) kebijakan paten di Indonesia pada tatanan makroekonomi, dan 2) aktivitas dan intensitas interaksi elemen SIN dalam menyikapi pentingnya kapabilitas inovasi dalam mendukung keberlanjutan dan daya saing di era global.

Dua pertanyaan muncul terkait dengan kinerja paten di Indonesia serta kebijakan paten sebagai sebuah bentuk kebijakan dalam mendorong inovasi. Pertama, mengapa pelaksanaan kebijakan paten belum berhasil meningkatkan aktivitas inovasi di Indonesia? Kedua, bagaimana elemen-elemen SIN di skala mikro menyikapi kebijakan paten terkait dengan aktivitas litbang dan inovasi yang dilakukan, maka dalam lingkup yang lebih besar, pemahaman terhadap kebijakan paten dan inovasi tersebut akan bermanfaat dalam proses penyusunan

$$
\text { 183|S A S I Vol. } 27 \text { No.2, April - Juni } 2021
$$


alternatif kebijakan paten dalam meningkatkan aktivitas inovasi di Indonesia. Berkaitan dengan hal tersebut, perlu dilakukan sebuah penelitian dengan tujuan: 1) menganalisis kebijakan paten di Indonesia dalam meningkatkan aktivitas inovasi, 2) mengidentifikasi motif elemen SIN (lembaga litbang, perguruan tinggi, dan industri) dalam mengapresiasi pemanfaatan paten terkait dengan aktivitas inovasi yang dilakukan; dan 3) menyusun alternatif kebijakan paten dalam meningkatkan aktivitas inovasi.

Dari sudut pandang fungsi pemerintah, berlangsungnya democratic government atau good governance (Pierre \& Peters, 2000) terkait dengan kapabilitas pemerintah dalam menciptakan berbagai kebijakan dan instrumen untuk menjaring partisipasi publik serta tugas dan wewenangnya dalam menciptakan keteraturan dan iklim yang kondusif di masyarakat. Aktivitas inovasi di sektor mikro memerlukan kebijakan yang komprehensif terkait dengan interaksi antar pelaku sistem inovasi. Pemerintah menjadi salah satu dari elemen sistem inovasi tersebut.

Penggunaan obat tradisional di Indonesia merupakan bagian dari budaya bangsa dan banyak dimanfaatkan masyarakat sejak berabad-abad yang lalu, namun demikian pada umumnya efektivitas dan keamanannya belum sepenuhnya didukung oleh penelitian yang memadai. Mengingat hal tersebut dan menyadari bahwa Indonesiasebagai mega-center tanaman obat di dunia, maka perlu disusun suatu kebijakan obat tradisional yang dapat menjadi acuan semua pihak yang terkait didalamnya.

Masyarakat di Maluku sudah sejak lama menggunakan tumbuhan pala baik buah, daun maupun rantingnya untuk pengobatan reumatik, sakit kepala dan peningkatan aktivitas seksual. Terdapat 216 jenis tumbuhan obat yang dimanfaatkan oleh masyarakat Maluku, untuk dapat memberikan jaminan mutu di bidang obat tradisional, yang dihadapkan pada kondisi sangat kurangnya ketersediaan standar dan metode sebagai instrumen untuk melakukan evaluasi mutu. Sebagaimana telah disbeutkan bahwa manfaat dan mutu obat tradisional dipengaruhi oleh banyak faktor. Sementara itu penelitan mengenai faktor-faktor tersebut sangat terbatas yang ada pada gilirannya menyebabkan terbatasnya data, standar dan metodologi.

Sumberdaya alam tumbuhan obat belum dikelola secara optimal dan kegiatan budidaya belum diselenggarakan secara profesional, karena iklim usaha yang tidak kondusif, tidak ada jaminan pasar dan harga. Hal ini berdampak pada pembudidayaan sebagai usaha sambian, sehingga bahan baku obat tradisional sebagian besar masih merupakan hasil pengumpulan dari tumbuhan liar dan tanaman pekarangan. Kegiatan eksploitasi jenis-jenis tumbuhan liar dan tumbuhan hutan tertentu untuk menjadi bahan obat tradisional masih terus berlangsung tanpa disertai dengan kegiatan budidaya, sehingga beberapa jenis tumbuhan telah menjadi tumbuhan langka, untuk mencegah terjadinya kepunahan, maka jenis tumbuhan langka tersebut perlu segera dilestarikan dengan mengupayakan kegiatan budidaya.

Upaya pengembangan obat tradisional kurang terkoordinasi dengan baik. Pihak-pihak terkait seperti Pemerintah, Industri, pendidikan dan penelitian, petani dan provider, kesehatan belum bekerjasama secara sinergis. Pembiayaan yang tersdia untuk pengembangan obat tradisional Indonesia terutama untuk membiayai kegiatan penelitian masih sangat jauh dari kebutuhan. Di satu sisi, kemampuan keuangan pemerintah masih terbatas, sedangkan di pihak lain, industri obat tradisional belum termotivasi untuk secara tanggung renteng ikut membiayai kegiatan penelitian.

Kegiatan usaha industri yang megnkhususkan diri untuk memproduksi bahan baku antara masih sangat sedikit. Mereka memproduksi bahan baku antara diutamakan untuk keperluan produksi produk jadi sendiri. Beberapa industri ekstrak di tanah air, belum berjalan secar optimal dan lebih banyak untuk memenuhi kebutuhan sendiri. Ekspor obat tradisional dan simplisis Indonesia, walaupun belum dalam jumlah yang besar, namun menunjkan tanda-tanda peningkatan. Sebagaimana disampaikan oleh Asosiasi Pengusaha Eksportir Tanaman Obat Tradisional Indonesia (Selanjutnya disebut APETOI) dan Informasi Gabungan Pengusaha Jamu 
dan Obat Tradisional serta Koperasi Jamu Indonesia, ekspor tumbuhan obat terus meningkat. Permintaan datang dari beberapa negara luar cukup besar, kadangkala untuk beberapa jenis tanaman Indonesia tidak dapat dipenuhi.

Semakin banyaknya tersedia hasil penelitian ilmiah yang menunjukan bahwa sediaan obat bahan alam terbukti mempengaruhi metabolisme tubuh dan memiliki efek terapi yang efektif. Efek sampng obat tradisional pada umumnya relatif jauh lebih rendah dibandingkan dengan obat-obat konvensional. Penggunaan obat tradisional terus meningkat baik di negara-negara berkembang maupun di negara-negara maju. Badan Kesehatan Dunia (WHO) melalui World Health Assembly merekomendasikan penggunaan pengobatan tradisional, ermauk obat tradisional, dalam pemeliharaan kesehatan masyarakat, pencegahan dan pengobatan penyakit, terutama untuk penyakit-penyakit kronis, penyakit-penyakita degerneatif, covid dan kanker.

Bioptracy oleh pihak asing terus berlangsung sementara banyak jenis tumbuhan obat yang terancam kepunahan belum sempat diteliti, dikembangkan dan dibudidayakan. Menurut Undang-Undang Nomor 5 Tahun 1990 tentang Konservasi Sumber Daya Alam dan Ekosistem, dan Undang-Undang Nomor 12 Tahun 1992 tentang Sistem Budidaya Tumbuhan, Pencaharian, dan Pengumpulan Plasmanuftah dalam rangka pemuliaan dilakukan oleh Pemerintah dan dalam kegiatannya dapat dilakukan oleh perorangan dan badan hukum yang diberi ijin khusus, sedangkan untuk pelestariannya dilakukan pemerintah bersama masyarakat, harus ada regulasi yang mengatur pertukaran sumber daya alam obat tradisional dan kearifan lokal melalui pembagian keuntungan yang ideal.

Beberapa obat tradisional telah digunakan untuk penyembuhan penyakit dan beberapa penelitian menunjukkan potensi obat tradisional digunakan dalam penyembuhan penyakit terutama penyakit degeneratif. Namun kadangkala harganya lebih mahal dibandingkan dengan obat konvensional. Tantangan untuk penelitan obat tradisional bukan hanya pembuktian khasiat dan keamananya, tetapi juga bagaimana mendapatkan obat tradisional yang lebih kompetitif dalam rasio biaya dan manfaat. Upaya pengembangan obat tradisional merupakan rangkaian keggiatan panjang, bidang yang luas dengan permasalahan kompleks serta melibatkan banyak pihak. Sementara itu sumber saya untuk itu sangatlah terbatas.

\section{PE N U T P}

Pentingnya peranan pencipta racikan obat alternatif tradisional untuk mencegah penularan covid 19 di Kota Ambon, salah satu obat mimpi dari pencipta racikan atau ramuan obat alternatif tradisional disebut obat sahoeroe telah memberikan kesembuhan bagi mereka yang menderita penyakit covid-19 di kota Ambon, khususnya warga masyarakat yang berdomisili di negeri Hative Besar dan Negeri Hukurila. Salah satu bentuk pranata hukum oleh Pemerintah Provinsi Maluku dalam memberikan hak paten bagi pencipta racikan (ramuan) obat alternatif tradisional (obat sahoeroe) sebagai kearifan lokal dalam menangani dan mencegah penularan covid 19 di kota Ambon.

\section{DAFTAR PUSTAKA}

\section{Jurnal}

[1] Anggraeni, A. D., Salahudin, S., Jamil, A. S., \& Rofida, S. (2021). Analisis Kualitatif Obat Tradisional Sebagai Agen Peningkatan Imunitas Tubuh dalam Melawan Covid-19 Di Surat Kabar Online Indonesia. JKM (Jurnal Kesehatan Masyarakat) Cendekia Utama, 8(2), 207226. DOI: https://doi.org/10.31596/jkm.v8i2.684.

[2] Aryanto, H. (2014). Pemanfaatan Pengetahuan Tradisional Indonesia Berdasarkan Potensi Daerah sebagai Modal Pembangunan. Jurnal Hukum \& Pembangunan, 44(2), 292-313, DOI: http://dx.doi.org/10.21143/jhp.vol44.no2.24.

[3] Dewi, Y. K., \& Riyandari, B. A. (2020). Potensi Tanaman Lokal sebagai Tanaman Obat 185|SASI Vo1. 27 No.2, April - Juni 2021 
dalam Menghambat Penyebaran COVID-19. Jurnal Pharmascience, 7(2), 112-128. DOI: http://dx.doi.org/10.20527/jps.v7i2.8793.

[4] Labetubun, M. A. H., Akyuwen, R. J., \& Pariela, M. V. G. (2018). Perlindungan Pengetahuan Tradisional Secara Sui Generis untuk Menyongsong Masyarakat Ekonomi Asean. Sasi, 24(1), 1-10.

[5] Labetubun, M. A. H. (2019). Penyelesaian Sengketa Hak Atas Logo (Suatu Kajian Overlapping Hak Cipta dan Merek). ADHAPER: Jurnal Hukum Acara Perdata, 5(1), 151166. https://doi.org/10.36913/jhaper.v5il.93.

[6] Marzuki, P. M. (1996). Pemahaman Praktis Mengenai Hak Milik Intelektual. Jurnal Hukum Ekonomi, FH UNAIR Edisi III

[7] Perdani, M. S., \& Hasibuan, A. K. (2021). Analisis Informasi Tanaman Herbal melalui Media Sosial ditengah Masyarakat pada Pandemi Covid-19: Sebuah Tinjauan Literatur. BENCOOLEN JOURNAL OF PHARMACY, 1(1), 11-25. DOI: https://doi.org/10.33369/bjp.v1i1.15589.

[8] Rato, D., Utomo, L., Jayantiari, I. G. A. M. R., Bustami, S., Tehupeiory, A., Trisia, M. A.,...\& Geme, M. T. (2020). Kearifan Lokal Masyarakat Hukum Adat dalam Mewujudkan Kedaulatan Pangan Ditengah Pandemi Covid 19. Journal of Indonesian Adat Law (JIAL), 455-455.

[9] Yessiningrum, W. R. (2015). Perlindungan Hukum Indikasi Geografis Sebagai Bagian Dari Hak Kekayaan Intelektual. Jurnal IUS Kajian Hukum dan Keadilan, 3(1), 42-53.

\section{Buku}

[10]Endang, P. (2005). Perkembangan Hukum Intellectual Property Right Kajian Hukum Terhadap Hak atas Kekayaan Intelektual dan Kajian Komparatif Hukum Paten. Bogor: Ghalia Indonesia.

[11]Djumhana, M., \& Djubaedillah, R. (2014). Hak Milik Intelektual (Sejarah Teori dan Prakteknya di Indonesia), Bandung: Penerbit Citra Aditya Bakti.

[12]Hilman, H., \& Romadoni, A. (2001). Pengelolaan \& Perlindungan Aset Kekayaan Intelektual: Panduan Bagi Peneliti Bioteknologi. Jakarta: British Council

[13] Rasy, V. (2013). 30 Tanaman Herbal Untuk Pengobatan Tradisional. Yogyakarta: Penerbit Sakti.

[14] Sardjono, A. (2004). Pengetahuan Tradisional: Studi Mengenai Perlindungan Hak Kekayaan Intelektual Atas Obat-Obatan. Jakarta: Fakultas Hukum Universitas Indonesia.

[15] Sardjono, A. (2010). Hak Kekayaan Intelektual Dan Pengetahuan Tradisional. Bandung: Alumni.

\section{Online/World Wide Web dan Lain-Lain}

[16] Aulia, M. Z. (2006). Perlindungan Hak Kekayaan Intelektual atas Pengetahuan Tradisional, Karya Tulis. Lomba Karya Tulis Mahasiswa Bidang Hukum Se-Jawa 2006 tanggal 24 November 2006 di UNS, Surakarta.

[17]Baskara, B. (2020). Rangkaian Peristiwa Pertama Covid-19. Kompas.id. https://www.kompas.id/baca/riset/2020/04/18/rangkaian-peristiwa-pertama-covid-19.

[18]Hawin, M. (2005), Perlindungan Pengetahuan Tradisional, Perlindungan dan Pemanfaatan Tradisional Knowledge Dalam Kerangka Otonomi Daerah, Makalah. Seminar setengah hari tanggal 20 Agustus 2005, Yogyakarta. 